How well does chlorophyll explain the seasonal variation in phytoplankton activity?

Lyngsgaard, Maren Moltke; Markager, Stig; Richardson, Katherine; Møller, Eva Friis; Jakobsen, Hans Henrik

Published in:

Estuaries and Coasts

DOI:

$10.1007 / \mathrm{s} 12237-017-0215-4$

Publication date:

2017

Document version

Publisher's PDF, also known as Version of record

Document license:

CC BY

Citation for published version (APA):

Lyngsgaard, M. M., Markager, S., Richardson, K., Møller, E. F., \& Jakobsen, H. H. (2017). How well does

chlorophyll explain the seasonal variation in phytoplankton activity? Estuaries and Coasts, 40(5), 1263-1275.

https://doi.org/10.1007/s12237-017-0215-4 


\title{
How Well Does Chlorophyll Explain the Seasonal Variation in Phytoplankton Activity?
}

\author{
Maren Moltke Lyngsgaard ${ }^{1,2}$ • Stiig Markager $^{2}$ - Katherine Richardson ${ }^{1}$ • \\ Eva Friis Møller ${ }^{2}$ - Hans Henrik Jakobsen ${ }^{2}$
}

Received: 5 July 2016 /Revised: 6 January 2017 / Accepted: 19 January 2017 / Published online: 6 February 2017

(C) The Author(s) 2017. This article is published with open access at Springerlink.com

\begin{abstract}
The seasonal variation in phytoplankton activity is determined by analysing 1385 primary production (PP) profiles, chlorophyll $a(\mathrm{Chl})$ concentration profiles and phytoplankton carbon biomass concentrations (C) from the period 1998-2012. The data was collected at six different stations in the Baltic Sea transition zone (BSTZ) which is a location with strong seasonal production patterns with light as the key parameter controlling this productivity. We show that the use of $\mathrm{Chl}$ as a proxy for phytoplankton activity strongly overestimates the contribution from the spring production to annual pelagic carbon flow. Spring (February and March) Chl comprised $16-30 \%$ of the total annual $\mathrm{Chl}$ produced, whereas spring $\mathrm{C}$ was much lower (8-23\%) compared to the annual C. Spring PP accounted for 10-18\% of the total annual PP, while the July-August production contributed 26-33\%, i.e. within the time frame when zooplankton biomass and grazing pressure are highest. That is, Chl failed in this study to reflect the importance of the high summer PP. A better proxy for biomass may be $\mathrm{C}$, which correlated well with the seasonal pattern of PP (Pearson correlation, $p<0.05$ ). Thus, this study suggests to account for the strong seasonal pattern in $\mathrm{C} / \mathrm{Chl}$ ratios when considering carbon flow in coastal systems. Seasonal data for PP were fitted to a simple sinusoidal wave model describing the seasonal distribution of PP in the BSTZ
\end{abstract}

Communicated by Hans W. Paerl

Maren Moltke Lyngsgaard

marenmo@gmail.com

1 Center for Macroecology, Evolution and Climate, Danish Natural History Museum, University of Copenhagen,

2200 Copenhagen, Denmark

2 Department of Bioscience, Aarhus University, 4000 Roskilde, Denmark and were proposed to present a better parameterizaton of PP in shallow stratified temperate regions than more commonly applied proxies.

Keywords Spring bloom primary production · Seasonal variation · Nutrient concentration · Primary production . Chlorophyll a $\cdot$ Phytoplankton biomass

\section{Introduction}

The phytoplankton spring bloom is the most conspicuous manifestation of pelagic phytoplankton activity in temperate and polar waters and has received much attention. Platt and Sathyendranath (2008) referred to the "spring bloom of phytoplankton" as "the most important event in the trophic calendar of the pelagic systems". It is true that seasonal data for chlorophyll $a(\mathrm{Chl})$ often show a very pronounced peak in the spring (see, e.g. Perry et al. 2008 or Tiselius et al. 2015) and spring blooms are associated with high secondary production (Kiørboe and Nielsen 1994). However, the high biomass of phytoplankton grazers during summer suggests that the pelagic primary production at this time of the year could be top-down controlled, i.e. that the primary production will not result in a build-up of phytoplankton biomass. Thus, there is reason to challenge the current assumption concerning the importance of the spring bloom to total annual primary production (PP).

When considering carbon flow in ecosystems, the main focus by definition should be on the production rate of phytoplankton carbon, i.e. PP and the fate of this carbon rather than on standing biomass. At any given point in time, biomass will be a function of the previous concentration plus gains (growth rate and advection) and loss rates (mortality generated through cell decay and grazing processes, advection and sedimentation). Of these processes, only growth rate can be expected to be directly correlated 
with PP normalized to biomass, so there is no a priori reason to expect the relationship between biomass and PP to be constant and, even less so, that the relationship between PP and Chl should be constant given the well-documented variability in the C/Chl ratio (see, e.g. Cullen 1982; Fennel and Boss 2003; Jakobsen and Markager 2016).

PP is dependent mainly upon light and nutrient availability, and because light intensities are greatest during summer, we test the hypothesis that the summer PP contributes more to the annual phytoplankton carbon production than the spring bloom. We carry out the study at a series of monitoring stations located in the Baltic Sea transition zone (BSTZ), i.e. a temperate estuarine coastal region where the classic seasonal pattern of peak Chl values during spring and low Chl during summer (Cushing 1959) has repeatedly been found (see Tiselius et al. 2015 for 28 years of PP and Chl from the Gullmar Fjord). Nutrient concentrations in surface waters are higher in winter and spring than during summer, but the high temperatures during summer increase grazing and remineralization rates which can serve as a source of nutrients for PP throughout the summer season (Kemp and Boynton 1984) and allow the phytoplankton to use the full potential of the higher summer surface irradiance. A further reason to hypothesize that PP might be higher than traditionally assumed during summer in this region is that the study area is permanently stratified. It has been shown previously that a significant proportion (in the order of 17\%) of annual PP occurs in the subsurface layer, where nutrient availability is high throughout the year. The highest proportion of subsurface layer to water column PP occurs during summer when light intensities are high (Lyngsgaard et al. 2014a). Ultimately, the aim of estimating pelagic PP is to describe the magnitude of carbon being introduced to the food web and how it supports energy flow in the ecosystem.

Technically, PP describes the rate of carbon fixation using light, and PP therefore indicates how fast the carbon becomes available to the food web. Nevertheless, it is often represented by a state variable proxy representing biomass, i.e. Chl or carbon in marine ecosystem models. It therefore becomes important to understand how these proxies relate to PP. From the considerations above, it seems likely that seasonal distributions of the biomass proxies such as Chl, often used to represent PP, may differ considerably from the seasonal distribution of PP, estimated from photosynthetic rate measurements. We therefore address the hypothesis that the importance of the spring bloom will be overestimated when Chl is used as a proxy to represent PP.

The aim of this study was to compare the seasonal production patterns generated from standing stock proxies ( $\mathrm{Chl}$ and phytoplankton carbon) to actual PP estimates. In particular, we compare the relative importance of the spring bloom to total for annual PP when biomass proxies and actual PP estimates are used. Chemical carbon measurements are exceedingly difficult and expensive to obtain, and the carbon measured will contain carbon not only from autotrophic phytoplankton but also from heterotrophs and detritus. Biomass carbon specific to phytoplankton can be estimated from microscopic phytoplankton analysis, and we therefore chose to examine this biomass proxy in relation to $\mathrm{Chl}$ and PP. We used 1385 phytoplankton carbon, $\mathrm{Chl}$ and PP profiles collected over a 15-year period from six stations at the entrance to the Baltic Sea. Because zooplankton grazing can influence the relationship between PP and phytoplankton biomass, we also modelled seasonal zooplankton grazing rates to describe seasonal differences, in the balance between top-down and bottom-up processes and phytoplankton biomass.

This study focusses specifically on the Baltic Sea entrance area, but the seasonal patterns in PP described in the model as well as the relationships between PP, Chl and phytoplankton carbon found here are likely to also be representative of other temperate coastal marine systems. Therefore, on the basis of the observations made here, we develop a simple empirical model of the seasonal variation in PP that can potentially serve as framework for the representation of PP in ecosystem models representing areas similar to the study region.

\section{Materials and Methods}

\section{Study Area}

Six locations were selected from the database of the Danish National Aquatic Monitoring and Assessment Program (DNAMAP) (Conley et al. 2002). All study sites were located in the BSTZ, the area between the Skagerrak and the Baltic Sea (Fig. 1). Typically, the stations are visited with a frequency of $>20$ year $^{-1}$. Station depths vary from $14 \mathrm{~m}$ (Aalborg Bight) to $51 \mathrm{~m}$ in The Sound (Table 1, Fig. 1).

The BSTZ is hydrographically dynamic and exhibits typical estuarine features. The area receives outflowing surface water from the Baltic Sea that has a freshwater surplus of $559 \mathrm{~km}^{3}$ year ${ }^{-1}$ and periodically inflows driven by westerly winds of heavy oceanic water from the Kattegat/Skagerrak region (Savchuk 2005). The circulation within the BSTZ is mainly driven by the water level difference between the Arkona Sea and the northern Kattegat. The surface salinity ranges from 10 to 14 in the south and reaches $20-25$ in the northern Kattegat. Bottom water salinity is about 32-34 (Gustafsson 2000). These conditions result in the water column being almost permanently stratified.

\section{Data Extracted from the National Database}

The database from DNAMAP includes physical, chemical and biological data collected in BSTZ waters since the 1980s. Different regional authorities were responsible for data 
Fig. 1 The Baltic Sea transition zone (BSTZ) and the location of the six study locations

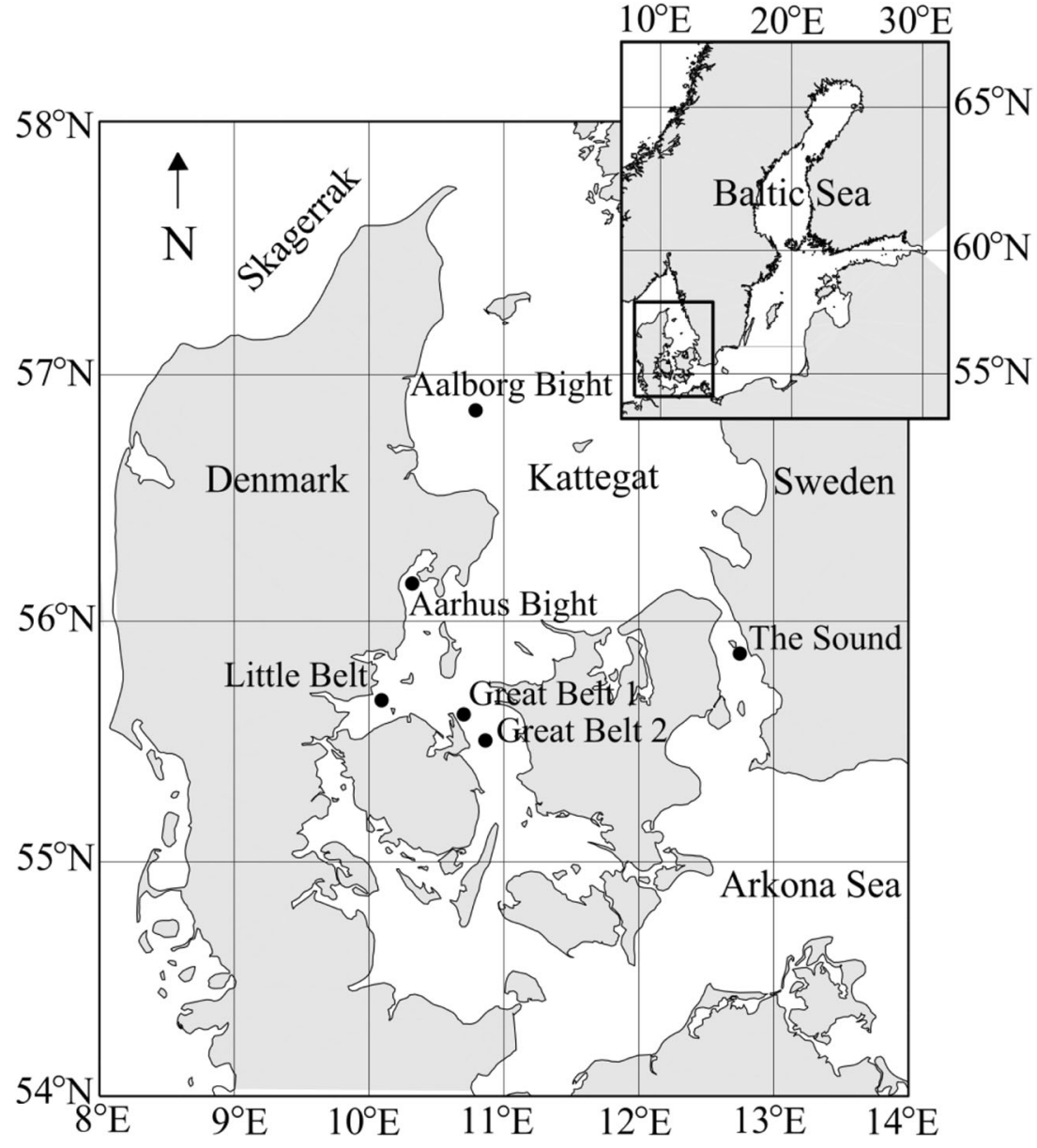

collection. However, all procedures were standardized in technical guidelines (Kaas and Markager 1998), and Aarhus University has frequently arranged workshops and intercomparisons of procedures/results to ensure the data quality.

Data on dissolved inorganic nitrogen and phosphorous concentrations from surface (average from 0 to $5 \mathrm{~m}$ ) and subsurface waters, phytoplankton biomass and size (year 19982012), sea surface (average from 0 to $5 \mathrm{~m}$ ) temperature (year 1998-2012), zooplankton biomass and size (only between 1998 and 2009) and photosynthesis (P) vs. light (E) curves

Table 1 Annual average primary production, annual spring, annual summer and grazing are presented as $\mathrm{g} \mathrm{C} \mathrm{m}^{-2}$ year $^{-1}$. The percentage of total annual primary production is noted in brackets. Standard deviation were extracted from the database, whereas parameters such as $\mathrm{PP}$, depth-integrated $\mathrm{Chl}$ and zooplankton potential grazing were calculated specifically for this study based on data in the database.

The daily surface photosynthetic active radiation (SPAR) was calculated as 30 min mean values from continuous measurements collected at three different localities in Denmark within approximately $30-150 \mathrm{~km}$ of the sample locations. The same SPAR dataset was used for the calculation of PP for all six stations.

in the top row shows the inter-annual variation of annual primary production. The depths of the stations are given in meters

\begin{tabular}{|c|c|c|c|c|c|c|c|}
\hline & Aalborg Bight & Aarhus Bight & The Sound & Little Belt & GB I & GB II & Average \\
\hline Annual PP & $161 \pm 25$ & $155 \pm 37$ & $175 \pm 53$ & $226 \pm 18$ & $213 \pm 12$ & $209 \pm 34$ & 190 \\
\hline Annual spring PP: Feb.-Mar. & $26(16)$ & $28(18)$ & $18(10)$ & $32(14)$ & $28(13)$ & $31(15)$ & $27(14)$ \\
\hline Annual summer PP: Jul.-Aug. & $44(27)$ & $41(26)$ & $53(30)$ & $66(29)$ & $69(33)$ & $60(29)$ & $56(30)$ \\
\hline Grazing (impact) & $127(79)$ & $112(72)$ & $95(54)$ & & & & $111(68)$ \\
\hline Depth of station & 14.0 & 16.6 & 51.0 & 19.5 & 21.9 & 35.0 & 26.3 \\
\hline
\end{tabular}




\section{Chlorophyll a}

The Chl concentration measurements were carried out by filtering samples onto Whatman GF/F or GF 75 Advantec filters. Filters were extracted in ethanol $(96 \%)$ for 6-20 h, and the extracts were analysed spectrophotometrically according to the method described by Strickland and Parsons (1972) and modified by Danish Standards (1986).

Chl fluorescence (F) through the water column was profiled continuously using a CTD-mounted fluorometer. Fluorescence per Chl changed systematically with depth in the dataset. Therefore, a fluorescence factor $\left(F_{\mathrm{chl}}=F /[\mathrm{Chl}]\right)$ was calculated, whereby the $\mathrm{Chl}$ recorded in the discrete sample and the fluorometer measurement from the corresponding depth $(\mathrm{F})$ were related. Values for $F_{\mathrm{chl}}$ for depths between the sampling depths of Chl (every $5 \mathrm{~m}$ ) were calculated by linear interpolation, which was done in $0.2-\mathrm{m}$ resolution, and then, $F_{\text {chl }}(z)$ values were used to estimate the $\mathrm{Chl}$ profile $(\mathrm{Chl}$ $\left.(z)=F(z) / F_{\text {chl }}(z)\right)$ in 20-cm depth intervals. Every Chl profile was depth-integrated before monthly average values were calculated.

\section{Estimating Vertical Water Column Primary Production}

To estimate water column PP, Chl-specific photosynthesis rates on samples taken from two depths were calculated from the photosynthesis $(\mathrm{P})$ vs. light $(\mathrm{E})$ curves and Chl concentrations in the database (details in Lyngsgaard et al. 2014a). Samples for $\mathrm{P}$ vs. E curves and $\mathrm{Chl}$ were taken as aliquots of the sample from surface and a deep Chl maximum. A light matrix representing the light intensities at $0.2-\mathrm{m}$ intervals through the water column at hourly intervals over each day was constructed using the attenuation coefficient and the surface light. Each of the 1385 PP profiles was constructed based on the Chl, light attenuation and P vs. E curve that was specific for that same time and site.

Briefly, photosynthetic carbon assimilation was estimated based on the carbon-14 method modified (Markager 1998) after Nielsen (1952). P vs. E curves were calculated from incubations made under artificial light (Osram HQI-T or high-pressure halogen lamps), where the samples were incubated at seven different light intensities for $2 \mathrm{~h}$ with metal grids providing approximately $35 \%$ light attenuation between each bottle. The P vs. E parameters were obtained by a nonlinear fitting procedure (Markager et al. 1999b) (Statistical Analysis System, SAS 9.4) on the carbon uptake divided by the Chl concentration. It was assumed that the P vs. E parameters from the surface sample represented an average value for the entire surface layer and these values were, therefore, extracted from the surface to the starting depth of the stratification layer. The reason for using the same P vs. E parameter values throughout the surface layer was that turbulence within this layer was assumed too high to allow further depth-specific photo adaptation (Lewis et al. 1984). Turbulence in the PBL was assumed to be lower, thus allowing more variation in the $\mathrm{P}$ vs. E parameter values with depth. Therefore, these were interpolated from the starting depth of the stratification layer (=surface values) to the second sampling depth. From the second sampling depth and downward, photosynthetic parameters were assumed to be constant (see Lyngsgaard et al. 2014a for figure and further description on interpolation details).

Data availability varied between stations and ranged from 3 to 14 years for the six stations. The sampling frequency at each station ranged from 12 to 49 measurements of $\mathrm{P}$ vs. E curves and $\mathrm{Chl}$ per year. For further detail on the data availability, see Table 1 in Lyngsgaard et al. (2014a).

Monthly PP (1998-2012) was calculated by multiplying the estimated daily PP (average when more than one measurement per month) by the number of days of the month for each station. Thereafter, average values of monthly PP were calculated across years for the sampling period. The spring PP was assumed to happen from 1 February to 31 March and was calculated both as the total production in these months and as the deviation from a sinusoidal curve representing seasonal variation in PP without the spring peak. Annual PP was calculated by summing the monthly averages for each station.

\section{Parameterization of the Seasonal Variation in PP}

The seasonal variation in PP could be empirically described as one half of a sinusoidal curve with a modification in the spring as follows:

$\mathrm{PP}=\mathrm{PP}_{\text {winter }}+\mathrm{PP}_{\text {amplitude }}((\cos (($ month-0.5-top $) / 12 \times 2 \times \pi-\pi)+1) \times 0.5)+\mathrm{PP}_{\mathrm{Feb}}+\mathrm{PP}_{\mathrm{Mar}}$

If month $\neq 2$, then $\mathrm{PP}_{\mathrm{Feb}}=0$. If month $\neq 3$, then $\mathrm{PP}_{\mathrm{Mar}}=0$.

The $\mathrm{PP}_{\text {winter }}$ is the level of winter $\mathrm{PP}$, and the $\mathrm{PP}_{\text {amplitude }}$ is the annual amplitude of PP (the maximum production minus the winter level). Month numbers are from 1 (January) to 12 (December), so the middle of the year is 6.5 , i.e. 1 July. The value of top (unit: month) adjusts the timing of the maximum in production, relative to 1 July (positive values equal a later peak). The constants $0.5,12,2, \pi$ and 1 are all necessary in order to use the conventional numbers for months as independent variables. The model has previously been used to 
estimate seasonal patterns in the $\mathrm{C} / \mathrm{Chl}$ ratio for the area (Jakobsen and Markager 2016). The parameters, $\mathrm{PP}_{\mathrm{Feb}}$ and $\mathrm{PP}_{\mathrm{Mar}}$, are added to account for spring bloom production. All parameters (Table 1) are fitted to average monthly values over the years for depth-integrated PP for each station by the procedure Proc NLIN in SAS 9.2.

\section{Biomass and Potential Grazing}

An integrated $(0-10 \mathrm{~m})$ sample was taken for phytoplankton and protozoan carbon estimates using an integration hose. The samples were fixed in acidified Lugols (2\% final concentration), identified and counted in an inverted microscope (Utermöhl 1958). The biovolumes of at least 10 cells of the most dominant species were determined in each sample using the appropriate geometric models (e.g. Hillebrand et al. 1999), whereas the biovolumes of the remaining phytoplankton were obtained from a standard table derived from the MAPS database (for details, see Jakobsen et al. 2015). Cell carbon was estimated by converting biovolumes to biomass using the carbon to volume relationship for protist plankton by Edler (1979).

Mesozooplankton samples were obtained using a submersible pump equipped with a $60-\mu \mathrm{m}$ net lifted through the water at $10 \mathrm{~m} \mathrm{~min}^{-1}$ (Mohlenberg 1987). Samples were preserved in 2$3 \%$ buffered formalin. Copepods and copepodites were identified to the taxonomic level possible, and biomass was calculated on the basis of length-carbon regressions from the literature or by fixed carbon values, specific to genus and stage (Breteler et al. 1982; Berggreen et al. 1988; Hay et al. 1991; Sabatini and Kiørboe 1994; Satapoomin 1999). Zooplankton carbon was then

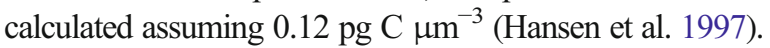

The potential grazing rates of protozooplankton (ciliates, heterotrophic dinoflagellates) and calanoid copepods on phytoplankton were calculated from the general equations of allometric scaling of maximum specific ingestion rates and maximum clearance rates presented by Hansen et al. (1997). Cyclopoid and harpacticoid copepods graze mostly on non-phytoplankton prey (Atkinson 1995; Koski and Kiørboe 2005). Their biomasses were generally less than $10 \%$ of the calanoid biomass, and they were, therefore, not considered. The estimated potential grazing rates were normalized to in situ temperature by applying a $Q_{10}$ value of 2.8 (Hansen et al. 1997).

It was assumed that ciliates grazed cells smaller than $10 \mu \mathrm{m}$ (equivalent sperical diameter (ESD)), whereas copepods and dinoflagellates grazed on particles larger than $10 \mu \mathrm{m}$ (Hansen et al. 1994). The fraction of phytoplankton larger than $10 \mu \mathrm{m}$ was obtained from the microscopial size measurements of the phytoplankton and applied to the biomass of phytoplankton calculated from $\mathrm{Chl}$ a using an average monthly carbon to $\mathrm{Chl}$ ratio for each station (Jakobsen and Markager 2016). The grazing rates were estimated either directly from maximum ingestion or calculated from the specific clearance rates multiplied by the concentration of potential food, calculated from
Chl. Furthermore, the smaller of the two grazing estimates (maximum ingestion or clearance $\times$ food concentration) was used for further calculations, assuming that grazing varied with food concentration but could never exceed maximum ingestion. Station-specific grazing was calculated by integrating results for the upper $25 \mathrm{~m}$ of the water column.

\section{Nutrients}

Values of dissolved inorganic nitrogen (DIN) and phosphorus (DIP) concentrations were extracted from the national database for the period 1998 to 2012. Sample depths were located at 5-m intervals starting at $1-\mathrm{m}$ depth. Samples for inorganic nutrients (nitrite $\left(\mathrm{NO}_{2}{ }^{-}\right)$, nitrate $\left(\mathrm{NO}_{3}{ }^{-}\right)$, ammonium $\left(\mathrm{NH}_{4}{ }^{+}\right)$, orthophosphate $\left(\mathrm{PO}_{4}{ }^{3-}\right)(\mathrm{DIP})$ and dissolved inorganic silicate $\left.(\mathrm{Si})\right)$ were stored frozen in 30-ml acid-washed plastic bottles. The inorganic nutrients were measured with flow injection on a scalar autoanalyser (Grasshoff et al. 1999). Detection limits were 0.04, 0.1, 0.3, 0.06 and $0.2 \mu \mathrm{mol}{ }^{-1}$ for $\mathrm{NO}_{2}^{-}, \mathrm{NO}_{3}^{-}, \mathrm{NH}_{4}{ }^{+}$, $\mathrm{PO}_{4}{ }^{3-}$ and $\mathrm{Si}$, respectively. DIN concentrations were calculated as the sum of the concentrations of $\mathrm{NO}_{2}{ }^{-}, \mathrm{NO}_{3}{ }^{-}$and $\mathrm{NH}_{4}{ }^{+}$. Average nutrient concentrations were calculated for two different depth regions: one from the surface (at $1 \mathrm{~m}$ ) and one from waters deeper than $10 \mathrm{~m}$. The average monthly nutrient concentrations were calculated across years (1998-2012).

\section{Results}

\section{The Physical and Chemical Environment}

The physical and chemical environment in the stratified BSTZ showed a marked seasonal variation. The average monthly SPAR peaked in June with a monthly average value of 39.8 mol photons $\mathrm{m}^{-2}$ day $^{-1}$. The peak in average surface water temperature $(0-5 \mathrm{~m})$ occurred 1.5 months later with a value of $17.9 \pm 1.9^{\circ} \mathrm{C}$ (Fig. 2a). SPAR increased markedly from February $\left(6.8 \mathrm{~mol}\right.$ photons $\left.\mathrm{m}^{-2} \mathrm{day}^{-1}\right)$ to March (15.9 mol photons $\mathrm{m}^{-2}$ day $^{-1}$ ).

DIN and DIP concentrations in the water column showed the highest values in January and February and declined thereafter (Fig. 2b, c). The average monthly surface DIN conc. was $<1 \mu \mathrm{mol} 1^{-1}$ from May to September, and average surface DIP conc. was $<0.1 \mu \mathrm{mol} \mathrm{l}^{-1}$ from May to August. The surface DIP concentration increased again in August to a value of $0.6 \mu \mathrm{mol}{ }^{-1}$ in December. Surface DIN increased 2 months later in October to a concentration in December of $6.3 \mu \mathrm{mol} 1^{-1}$. The highest surface summer (May to September) DIN and DIP concentrations were found in the belts (Little Belt, Great Belt I and Great Belt II, average DIN $=1.23-1.52 \mu \mathrm{mol} \mathrm{l}^{-1}$, average DIP $=0.22$ $0.33 \mu \mathrm{mol} \mathrm{l}^{-1}$ ). This was due to entrainment of deep water into the surface water due to higher currents in the narrow 

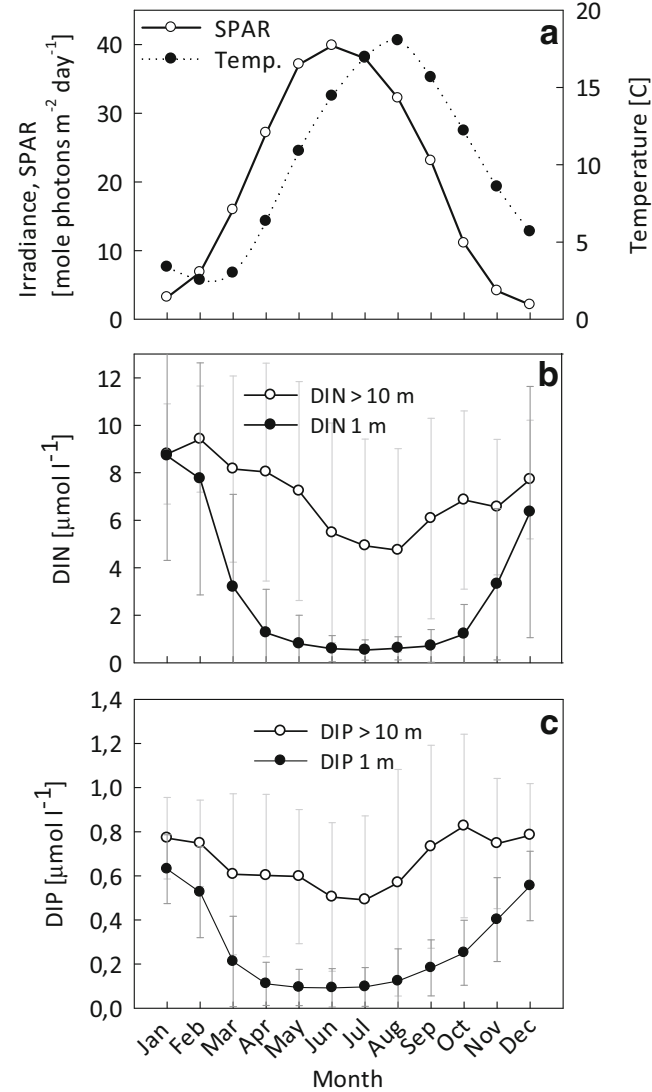

Fig. 2 Average monthly surface irradiance (SPAR) and temperature (average of $0-5 \mathrm{~m}$ ) for the six locations in the Baltic Sea transition zone (a). Dissolved inorganic nitrogen (b) and phosphorous (c) are shown as average monthly values for surface waters $(1 \mathrm{~m})$ and waters deeper than $10 \mathrm{~m}$. The standard deviation is shown as vertical bars for surface nutrients (dark grey) and for bottom water nutrients (light grey)

straits (Lund-Hansen et al. 2008). Lower surface values were found in the Aalborg and Aarhus Bights with average DIN values ranging from 0.55 to $0.76 \mu \mathrm{mol} \mathrm{l}^{-1}$ and average DIP values ranging from 0.07 to $0.1 \mu \mathrm{mol} \mathrm{l}^{-1}$. The range indicates the variation between average values for each station from May to September.

\section{Seasonal Variation in Primary Production}

The mean annual PP from 1998 to 2012 for the six stations was $190 \mathrm{~g} \mathrm{C} \mathrm{m}^{-2}$ year $^{-1}$ with an inter-annual variation in the annual mean of $\pm 17.2 \mathrm{~g} \mathrm{C} \mathrm{m}^{-2}$ year $^{-1}$. The lowest production estimates were found in Aalborg Bight, Aarhus Bight and The Sound (155-175 $\mathrm{g} \mathrm{C} \mathrm{m}^{-2}$ year $^{-1}$ ) most likely due to less intense mixing/stronger or longer stratification found at these stations, while the production in Great and Little Belts was higher (209-226 g C m${ }^{-2}$ year $^{-1}$, Table 1). The higher values at these stations probably reflect nutrient inputs from below the stratification layer to surface waters through more intense mixing in the narrow straits (Lund-Hansen et al. 2008).
The seasonal variation in the PP showed a pattern similar to the seasonal variation in surface irradiance and temperature but with a time lag in peak values (Fig. 3, see Fig. 2 for temperature and light) and a deviation in spring months. The highest monthly PP rates occured in July and August (average $837 \pm 185 \mathrm{mg} \mathrm{C} \mathrm{m}^{-2}$ day $^{-1}$ between stations) and lowest rates during winter (November, December and January). The summer production (July and August) contributed with $56 \mathrm{~g} \mathrm{C} \mathrm{m}^{-2}$ year $^{-1}$ or $30 \%$ of the annual production. For comparison, the two spring months February and March had a production of $27 \mathrm{~g} \mathrm{C} \mathrm{m}^{-2}$ year $^{-1}$ or $14 \%$ of the annual PP (see Table 1). The pattern of peak PP during summer was consistent for all six stations (see Fig. 3), and the timing of the summer peak production varied only between July and August, whereas the timing of the spring peak production varied from February to May, however most frequently occurring in March (Figs. 3 and 4). In April and May, there was found a noticeable decrease in PP before the rate started increasing once more (Fig. 3). The decrease in PP values during this time was concurrent with low nutrient concentrations (Fig. 2).

The seasonal variation in PP daily rates can be empirically described as one half of a sinusoidal curve with a characteristic timing of the peak and amplitude of the oscillation in PP (see Eq. 1). In this fashion, the seasonal variation in PP, in any of the six stations, is characterized by a winter PP value, a spring value and a summer amplitude value. Equation 1 fitted the monthly PP values well $p<0.0001$ (see Fig. 3), with $R^{2}$ values ranging from 0.90 in Aalborg Bight to 0.99 in Great Belt 2 (see Fig. 3 and Table 2 for station-specific model parameters). The values for the timing of the peak in PP (top) (Table 2) varied from 0.3 (10 July) to 1 (1 August). The amplitude varied from 680 to $1064 \mathrm{mg} \mathrm{C} \mathrm{m}{ }^{-2}$ day $^{-1}$ (average $909 \mathrm{mg} \mathrm{C} \mathrm{m}^{-2}$ day $^{-1}$ ) or about 30 -fold above the winter PP value. The winter values of $P P$ ranged from 0 to $92 \mathrm{mg} \mathrm{C} \mathrm{m}^{-2} \mathrm{day}^{-1}$ with an average value of $32 \mathrm{mg} \mathrm{C} \mathrm{m}^{-2}$ day $^{-1}$. The sum of $\mathrm{PP}_{\text {winter }}$ and $\mathrm{PP}_{\text {amplitude }}$ varied from 825 to 1076 (average 941) $\mathrm{mg} \mathrm{C} \mathrm{m}^{-2}$ day $^{-1}$ and provides an estimate of the maximum daily production. The deviation from the sine curve occurring in connection with spring bloom PP in February and March was between 6 and 14\% (sum of $\mathrm{PP}_{\mathrm{Feb}}$ and $\mathrm{PP}_{\mathrm{Mar}}$ as percent of annual production, Table 1) or 9\% as a mean for the six stations. Residuals show positive values in April (Fig. 4) indicating that, in some years, the spring bloom continues into April, and positive residuals in August and September indicate the presence of a weak bloom in late summer/autumn.

\section{Seasonal Distribution of Chlorophyll $a$ and Phytoplankton Biomass}

The seasonal variation in depth-integrated $\mathrm{Chl}$ concentrations was different from the seasonal PP pattern. Both variables started out with an increase in February and March, and at 

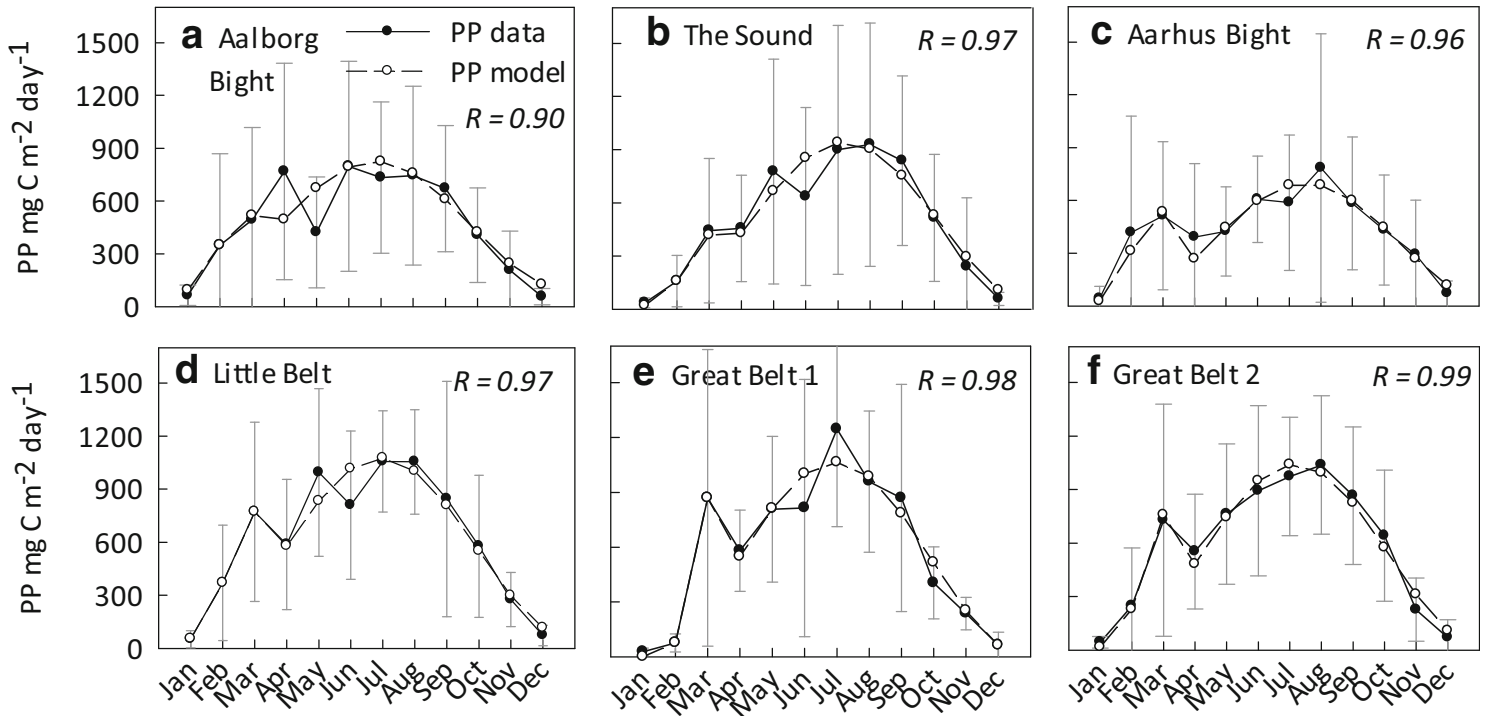

\section{Month}

Fig. 3 Average monthly primary production from 1998-2012 together with modelled values (Eq. 1) is shown for every month of the year at six different locations (a-f). The model fit to data is shown in $R$ values in the

four out of six stations, these months showed the highest $\mathrm{Chl}$ values over the year. In The Sound, higher values were recorded in May and June, and in Little Belt, Chl was highest during fall. Chl was low and relatively constant during the months from May to September (see Fig. 5), mean

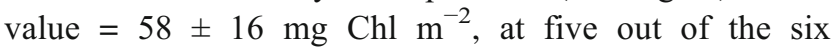
locations. The classical autumn bloom peak was noted for $\mathrm{Chl}$ for all stations in October and November (mean $=81 \pm 27 \mathrm{~g} \mathrm{Chl} \mathrm{m}^{-2}$ ). An increase was, however, not seen for PP in any of the stations. Thus, the seasonal variation for phytoplankton activity showed very different patterns depending on which proxy, Chl or PP that was evaluated.

For three of the six stations, Aalborg and Aarhus Bights and The Sound, phytoplankton carbon biomass was also calculated and compared to PP. This analysis reveals a pattern far more compatible with the seasonal variation in PP than when PP was compared to Chl (Pearson correlation, $p<0.05$ ) (see Table 3). The distinctive spring and autumn peaks observed in the Chl distributions were not reproduced in the seasonal variation of the phytoplankton carbon biomass. In this case, the highest phytoplankton biomass was found during the summer season concurrent with the highest values of PP (Fig. 5). The Aalborg Bight did however show concurrent peaks in July for PP, carbon biomass and Chl; the PP peak is, however, broader than the summer peak in $\mathrm{Chl}$ and $\mathrm{C}$. Average monthly estimates of phytoplankton carbon biomass were significantly and positively correlated with PP at all three stations (Table 3) (Pearson correlation, $R=0.60_{\text {Aalborg Bight }}, R=0.75_{\text {The Sound }}$, $R=0.80_{\text {Aarhus Bight, }} p<0.05$ ). In contrast, only at one station (The Sound) was there a correlation between $\mathrm{Chl}$ concentration and PP (Pearson correlation, $R=0.72, p<0.05$ ). upper right corner. Standard deviation bars indicate the inter-annual variation of each monthly value

\section{Grazing}

The seasonal variation of zooplankton biomass and grazing rates exhibited similar patterns to the PP and phytoplankton carbon biomass with distinct mid-summer peaks (Fig. 6). The copepod biomass was highest from May to June, whereas their grazing peaked in the June to August period. Here, it must be noted that the increased grazing rates are due to the nature of calculations, since there is a prescribed temperature dependence of ingestion rates. Protozooplankton biomass peaked in spring (March-April) and fall (SeptemberOctober) and was low during summer when the copepod biomass and grazing impact were highest (Fig. 6). The total potential grazing impact increased from March, peaked in JuneAugust and decreased again in October-November (Fig. 6). The grazing rates were close to or above $100 \%$ of PP from

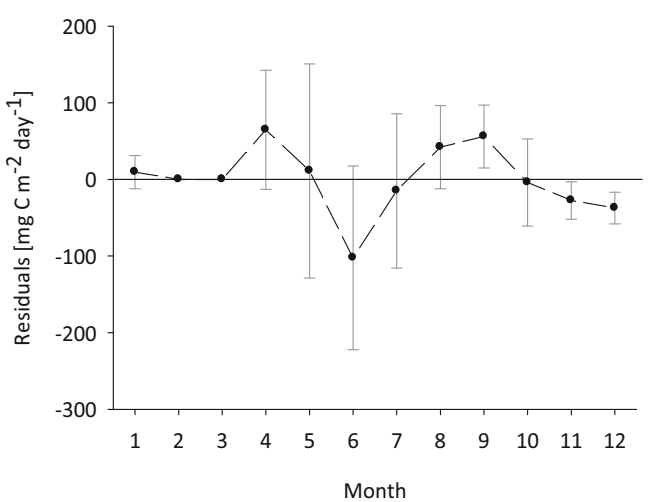

Fig. 4 Average monthly residual values (in situ data - model data) are shown from the model fit by Eq. 1 calculated for six stations. The vertical bars are the standard deviation from average values 
Table 2 Estimated parameters in Eq. 1 (see also Fig. 3) for the six stations. $\mathrm{PP}_{\text {winter }}, \mathrm{PP}_{\text {amplitude }}$ and spring bloom $\mathrm{PP}$ are given in $\mathrm{mg}$ $\mathrm{C} \mathrm{m}^{-2}$ day $^{-1}$. Annual $\mathrm{PP}$ is given in $\mathrm{g} \mathrm{C} \mathrm{m}^{-2}$ year $^{-1}$. The top parameter is the deviation in months from July 1 (positive values = a later peak), and the bottom row spring PP (February + March) is given in \% of annual PP

\begin{tabular}{|c|c|c|c|c|c|c|c|}
\hline & Aalborg Bight & Aarhus Bight & The Sound & Little Belt & GB I & GB II & Average \\
\hline $\mathrm{PP}_{\text {winter }}$ & 92 & 17 & 16 & 54 & 0 & 14 & 32 \\
\hline $\mathrm{PP}_{\text {amplitude }}$ & 733 & 925 & 680 & 1022 & 1064 & 1027 & 909 \\
\hline Maximum PP $\left(\mathrm{PP}_{\text {winter }}+\mathrm{PP}_{\text {amplitude }}\right)$ & 825 & 942 & 696 & 1076 & 1064 & 1041 & 941 \\
\hline Top & 0.3 & 0.7 & 1.0 & 0.4 & 0.4 & 0.7 & 0.6 \\
\hline Spring bloom PP, February & 187 & 103 & 284 & 241 & -3 & 167 & 163 \\
\hline Spring bloom PP, March & 209 & 211 & 418 & 450 & 590 & 525 & 400 \\
\hline Annual PP & 180 & 185 & 152 & 228 & 213 & 215 & 196 \\
\hline Spring bloom PP & 6.5 & 5.1 & 13.8 & 9.1 & 8.5 & 9.8 & 8.8 \\
\hline
\end{tabular}

May to August indicating high activity by phytoplankton not included in the PP rates such as mixotrophic and heterotrophic groups. Furthermore, it indicates that organic material produced through PP was consumed as soon as it was produced, suggesting top-down control of phytoplankton biomass during this time. In carbon units, the sum of the annual potential grazing ranged from 95 to $127 \mathrm{~g} \mathrm{C} \mathrm{m}^{-2}$ year ${ }^{-1}$ corresponding to 54 to $79 \%$ of the annual PP (Table 1). The grazing impact varied from 10 to $30 \%$ of PP in winter and increased to above $100 \%$ in mid-summer (Fig. 6). Thus, a significant correlation between grazing and the seasonal succession in PP was found (Table 3) (Pearson correlation, $p<0.05$ and $p<0.001$ ).

The potential grazing from protozooplankton was higher than the copepod grazing in Aarhus Bight (62\% of total grazing for protozoans versus $38 \%$ for copepods), whereas the copepod grazing was highest in Aalborg Bight (65\% of total grazing for copepods versus $35 \%$ for protozoans). Grazing pressure by copepods and protozooplankton was approximately equal in The Sound, suggesting considerable differences in the structure of planktonic food webs between the stations.

\section{Discussion}

Although often used in modelling exercises as proxies for PP, this study shows that $\mathrm{Chl}$ is a poor proxy for PP, especially during summer. This result is not in itself surprising given the myriad studies that have demonstrated non-constant relationships between the $\mathrm{C} / \mathrm{Chl}, \mathrm{C} / \mathrm{PP}$ and $\mathrm{Chl} / \mathrm{PP}$ ratios (Eriksen and Iversen 1995; Tang 1996; Henriksen et al. 2002; Domingues et al. 2011; Morán and Scharek 2015; Jakobsen and Markager 2016). This study builds upon empirical knowledge and opens up the next chapter regarding description and comparison of the seasonal patterns in standing stock biomass and PP, that
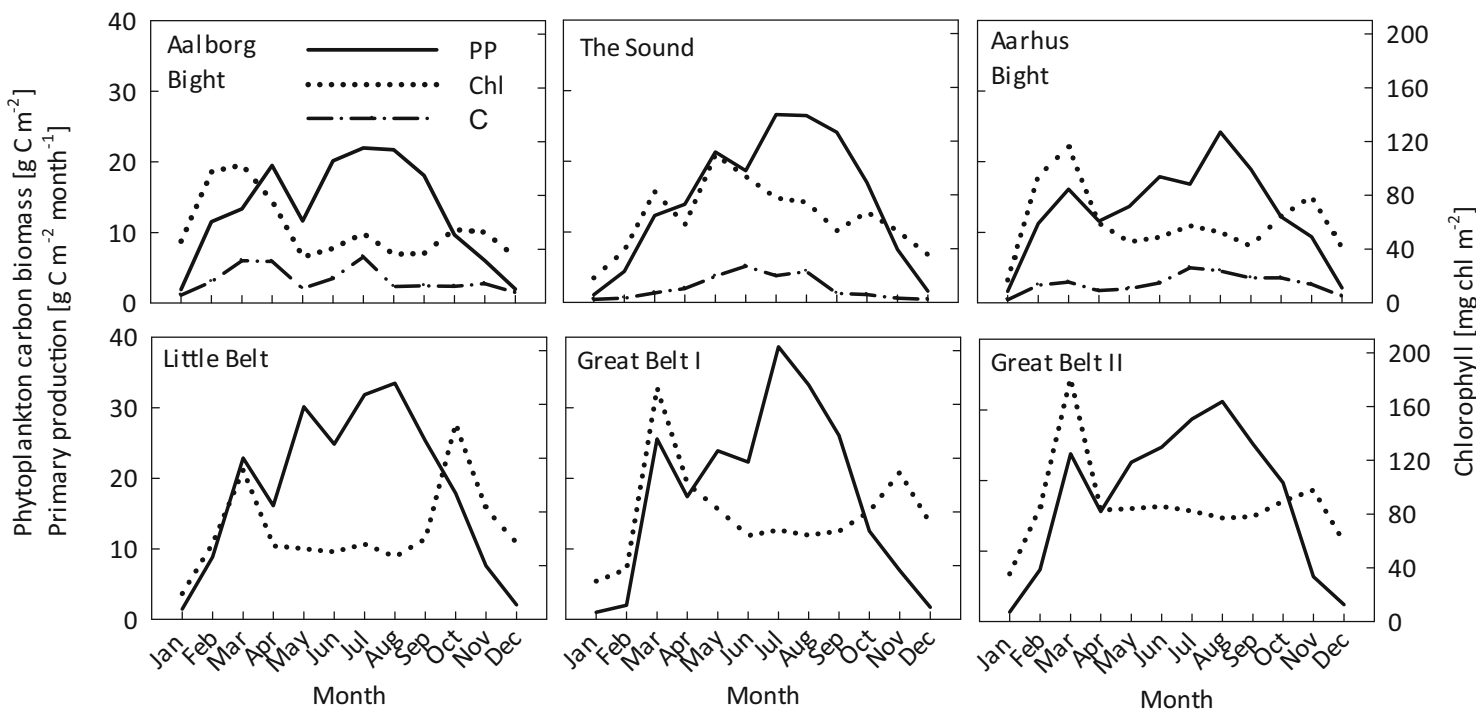

Fig. 5 Average monthly values of total water column primary production, Chl and phytoplankton carbon for six locations in the Baltic Sea transition zone (phytoplankton carbon only on three stations) 
Table 3 Pearson correlations between the average monthly values of primary production ( $n=12$ for each station) and the following variables: depthintegrated $\mathrm{Chl}$, autotrophic phytoplankton carbon (derived from the $\mathrm{Chl}$ and $\mathrm{C} / \mathrm{Chl}$ ratio) and grazing

\begin{tabular}{|c|c|c|c|c|c|c|}
\hline & \multicolumn{6}{|c|}{ Primary production } \\
\hline & Aalborg Bight & The Sound & Aarhus Bight & Little Belt & Great Belt I & Great Belt II \\
\hline Chl & $R=0.04$ & $R=0.72$ & $R=0.26$ & $R=0.09$ & $R=0.26$ & $R=0.40$ \\
\hline Carbon & $R=0.60$ & $R=0.75$ & $R=0.80$ & & & \\
\hline Grazing & $R=0.80$ & $R=0.83^{*}$ & $R=0.85^{*}$ & & & \\
\hline
\end{tabular}

$R$ values in italic indicate a significant relationship at the $p<0.05$ level; $* p<0.001$ level

can potentially be useful in describing this and similar temperate stratified coastal systems.

The study is also important as it reminds us that assumptions on ecosystem functioning based on easily obtained observations of Chl may be highly misleading. Here, we show that using $\mathrm{Chl}$ as a proxy for phytoplankton biomass overestimates the importance of the spring bloom. The apparent importance of the spring bloom in the seasonal plankton cycle decreases when phytoplankton activity is represented by carbon biomass estimated microscopically. When phytoplankton activity is represented by PP, the decrease is even more noteworthy. On average, only $14 \%$ of annual PP occurred in the spring months February through March. In comparison, 29\% of the annual PP occurred in July through August suggesting that this period is the most productive period despite low phytoplankton standing stock at this time. Thus, while the spring bloom, with its associated accumulation of Chl, usually displays the most conspicuous phytoplankton event during the calendar year, it does not represent the highest carbon flow through the food web. As Chl determinations are fast and inexpensive in comparison to PP estimates, $\mathrm{Chl}$ is often the proxy of choice for describing spatial and temporal distribution patterns in phytoplankton activity (see, e.g. Henson et al. 2010). Numerous studies (e.g. Conley et al. 2000; Timmermann et al. 2010; Carstensen et al. 2011 and references therein) assume a direct link between nutrient input
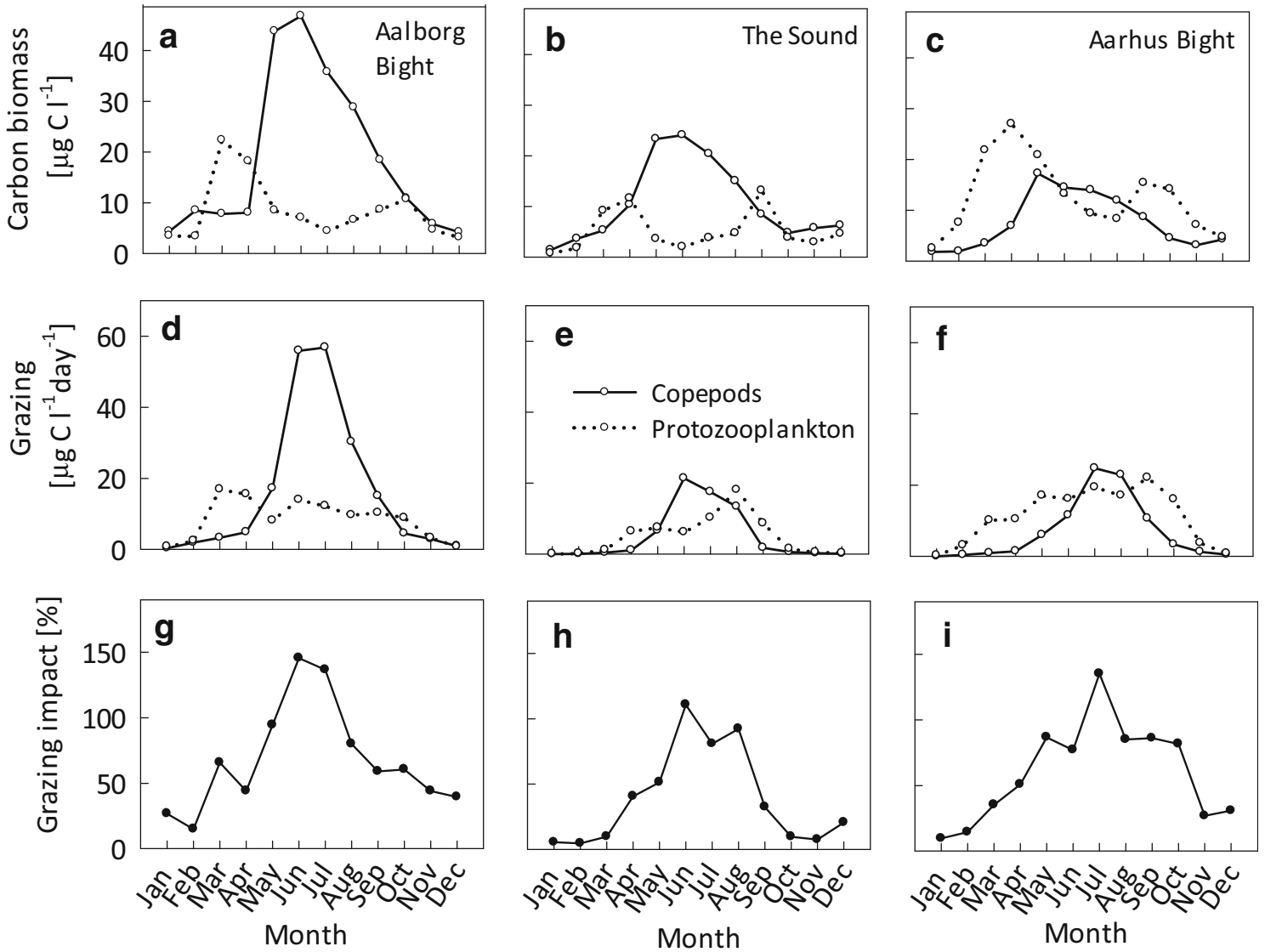

Fig. 6 Zooplankton biomass (top row $\mathbf{a}-\mathbf{c}$ ), potential grazing (middle row $\mathbf{d}-\mathbf{f}$ ) and total grazing impact on primary production (bottom row $\mathbf{g - i}$ ) for copepods and protozooplankton in Aalborg Bight $(\mathbf{a}, \mathbf{d}, \mathbf{g})$, The Sound $(\mathbf{b}, \mathbf{e}, \mathbf{h})$ and Aarhus Bight $(\mathbf{c}, \mathbf{f}, \mathbf{i})$ 
and $\mathrm{Chl}$ as a biomass proxy. However, any relationship between nutrient input and phytoplankton biomass would have to operate through PP.

The ratio between carbon and $\mathrm{Chl}$ in phytoplankton cells varies dependently on the environment surrounding them. There is a considerable span in the $\mathrm{C}$ to $\mathrm{Chl}$ ratio reported (from 6 to 333) from the literature based on lab studies (Falkowski et al. 1985; Geider 1987), and even within the BSTZ, which is a relatively small region, $\mathrm{C}$ to $\mathrm{Chl}$ ratios vary up to 7-fold from 10 in the winter and up to almost 60 during summer (Jakobsen and Markager 2016). Light has a direct effect on the $\mathrm{C}$ to $\mathrm{Chl}$ ratio and has been shown to increase the $\mathrm{C}$ to $\mathrm{Chl}$ ratio especially in low-temperature regions (Yoder 1979; Verity 1981). In this study, the seasonal variation recorded in $\mathrm{C}$ to $\mathrm{Chl}$ ratios, and the poor correlation between the two parameters, can be explained by several environmental factors. For instance, the pigment composition varies with the different phytoplankton groups where dinoflagellates, for example, generally have a higher $\mathrm{C}$ to $\mathrm{Chl}$ ratio than diatoms (Geider 1987; Tang 1996). Therefore, a seasonal decoupling of $\mathrm{C}$ and $\mathrm{Chl}$ will occur because (1) the dynamic pigment composition within phytoplankton cells is highly influenced by nutrients, temperature and irradiance (Eriksen and Iversen 1995; Henriksen et al. 2002; Domingues et al. 2011) and (2) because the species composition of the phytoplankton community changes through the different seasons of the year in temperate waters (see, e.g. Holligan and Harbour 1977; Domingues et al. 2005). The phytoplankton carbon examined in this study did correlate with the primary production, which means that phytoplankton biomass does relate to PP in stratified estuarine ecosystems, but the relationship is poor when phytoplankton biomass is expressed as Chl.

\section{Relevance to Modelling of Carbon Flow in Dynamic Ecosystems}

Parameterizing PP is challenging as sufficient data for PP in a given area are seldom available. Measurement of parameters relevant to estimating PP is time consuming, requires skilled staff and is expensive, and the results are highly variable even within the same week not to mention the range of challenges when comparing PP measured by different lab staff and local modification of methods (see Peterson 1980; Richardson 1991).

This study suggests that it is possible to generalize the seasonal pattern in PP in a fashion that may be applicable for modeling of carbon flow in dynamic ecosystems, as the underlying seasonal dynamics in PP appears to follow the seasonal temperature and light curves. Thus, it appears that light and temperature ultimately are the main modulators of seasonal PP dynamics. This is not overly surprising, because light is the only resource directly controlling carbon fixation and corroborates with the work by Morán and Estrada (2005) which identified light as the primary controlling factor for photosynthetic parameters in western Mediterranean waters. However, other factors such as nutrient concentration and grazing are important drivers that govern the timing and amplitude in PP creating station-specific patterns.

The widespread use of ecosystem models where the temporal distribution of phytoplankton production is assumed to be controlled by $\mathrm{N}$ availablity may therefore underestimate the importance of the summer PP with regard to ecosystem carbon flow. A recent study by Maar et al. (2016) shows that formulation of PP which allows carbon fixation to occur, also under periods with low nutrient availability, yielded a better fit to in situ PP determinations than when PP was assumed to be a direct function of nutrient concentrations. This approach particularly improved the description of the vertical distribution of PP in the water column.

Temperature has two major effects on PP. One is that it affects the physiological processes within the algal cell (Eppley 1972; Thompson 2005). The photosynthetic parameters used to derive the PP estimates in this study are described in detail in Lyngsgaard et al. (2014a) and are not included here (see Lyngsgaard et al. 2014a, Fig. 4). The data shows that the average monthly $P_{\max }$ values covary with temperature and peak in August concurrent with the temperature peak, which indicates that temperature directly affects $P_{\max }$ (Anning et al. 2001) due to enzyme-driven processes. Temperature also has an indirect effect on PP in that higher temperatures increase remineralization rates and thereby increase nutrient availability for phytoplankton production (Kemp and Boynton 1984). Warmer temperatures can, furthermore, stabilize the water column by introducing a stratification layer which promotes higher light availability and, in turn, leads to bloom situations (Cloern et al. 2014). Tiselius et al. (2015) examined 28 years of frequent PP measurements carried out every second week in the Gullmar Fjord and found very similar patterns to the ones found in this study. The results showed that $\mathrm{PP}$ was highest during summer concurrent with high zooplankton grazing rates and concluded that the phytoplankton community was top-down controlled during this peak season. Also, Tiselius et al. (2015) found Chl patterns that did not correlate with PP. Additionally, a study from the Chesapeake Bay covering 20 years of PP on six stations showed the same patterns of high summer productivity (Gallegos 2014) as is presented in this study. Thus, it seems likely that the general pattern for the seasonal variation in PP, described for the study area, the Chesapeake Bay and for the Gullmar Fjord, could very well be found in other temperate and possibly polar regions. The parameterization developed in this study may therefore be applicable to other regions.

\section{Impact of Zooplankton Grazing on Phytoplankton Standing Stock}

The main reason for the decoupling of PP and Chl patterns during summer is the seasonal variation of $\mathrm{C} / \mathrm{Chl}$ ratios (see 
Jakobsen and Markager 2016); however, this can also be explained by grazing activity. Examples of situations where $\mathrm{Chl}$ measurements have been shown to deviate from the seasonal pattern of PP typically arise under high grazing pressures (Cloern 1982; Nielsen et al. 1993; Pomeroy et al. 2006; Tiselius et al. 2015). The results from this study show a clear maximum grazing rate during the summer months suggesting that the summer period is the most productive season in this coastal ecosystem. However, because of high grazing rates, PP is funnelled very effectively through the food chain during summer, especially from May to August, confirming earlier studies carried out for shorter time periods in the region (see, e.g. Kiørboe 1993; Markager et al. 1999a; Hansen et al. 2002; Zervoudaki et al. 2009).

Here, we estimate the potential grazing on phytoplankton biomass in the range of $10 \%$ in the winter to $>100 \%$ during summer which in annual terms corresponds to $54-79 \%$ of the phytoplankton biomass. It is interesting that our conversion of zooplankton grazer biomass into grazing rates compares well with the dilution methods which typically yields grazing rates $\sim 60-75 \%$ of the daily PP (Calbet and Landry 2004).

Classically, the importance of the spring bloom for zooplankton grazing and reproduction (Cushing 1972) has been strongly emphasized, whereas less attention has been drawn to the mechanistics fueling zooplankton nutrition during the warmer summer months (Kiørboe and Nielsen 1994). In this study, the highest rates of PP were recorded in July-August (Fig. 3). Thus, the timing of the seasonal PP peak coincides with the seasonal maximum in zooplankton biomass and grazing rates recorded which is supported by earlier findings in the BSTZ (Kiørboe and Nielsen 1994; Zervoudaki et al. 2009). The PP occurring in and below the pycnocline contributed significantly (6-30\%) to the annual PP, especially from April to September (range from 25 to 35\%) (Lyngsgaard et al. 2014a). This suggests that PP occurring deeper in the water column is an important food source for zooplankton that can migrate vertically and may represent a different type of food source than the one apparent in surface waters (Lyngsgaard et al. 2014b). To maintain high zooplankton biomasses at summer temperatures requires a higher food intake, and zooplankton community net grazing rates are undoubtly greatest at these times rather than during the spring bloom.

\section{Conclusion}

This study is based on a very large number of PP profiles allowing a uniquely detailed description of seasonal patterns in PP and in its relationship to various parameters used to characterize the productivity of a coastal ecosystem. We show that using $\mathrm{Chl}$ as a proxy fails to provide a good representation of phytoplankton activity and suggest that alternative proxies should be sought for modelling studies. An equation describing the seasonal variation of PP from only three parameters is suggested for inspiration to modellors working with seasonal carbon flow in coastal systems describing the high summer productivity. The general seasonal pattern in PP presented here questions the general assumption that spring (bloom) PP is the key event in the annual carbon input to the planktonic food web and may also explain why grazers maintain high biomasses during the summer season.

Acknowledgements This study received funding from grant numbers 2104-09-063212 and 2104-09-67259 from the Strategic Research Council of Denmark. Additional support was received from the Danish National Research Foundation via a grant to the Center for Macroecology Evolution and Climate, University of Copenhagen and from the Department for Bioscience, Aarhus University. We thank the Department for Bioscience, Aarhus University for access to the monitoring data. We also thank Morten Holtegaard Nielsen for producing the map of the research area and all the numerous people that have collected the data over decades enabling this contribution.

Open Access This article is distributed under the terms of the Creative Commons Attribution 4.0 International License (http:// creativecommons.org/licenses/by/4.0/), which permits unrestricted use, distribution, and reproduction in any medium, provided you give appropriate credit to the original author(s) and the source, provide a link to the Creative Commons license, and indicate if changes were made.

\section{References}

Anning, T., G. Harris, and R. Geider. 2001. Thermal acclimation in the marine diatom Chaetoceros calcitrans (Bacillariophyceae). European Journal of Phycology 36: 233-241.

Atkinson, A. 1995. Omnivory and feeding selectivity in five copepod species during spring in the Bellingshausen Sea, Antarctica. ICES Journal of Marine Science: Journal du Conseil 52: 385-396.

Berggreen, U., B. Hansen, and T. Kiørboe. 1988. Food size spectra, ingestion and growth of the copepod Acartia tonsa during development: implications for determination of copepod production. Marine Biology 99: 341-352.

Breteler, W.C.M.K., H.G. Fransz, and S.R. Gonzalez. 1982. Growth and development of four calanoid copepod species under experimental and natural conditions. Netherlands Journal of Sea Research 16: 195-207.

Calbet, A., and M.R. Landry. 2004. Phytoplankton growth, microzooplankton grazing, and carbon cycling in marine systems. Limnology and Oceanography 49: 51-57.

Carstensen, J., M. Sánchez-Camacho, C.M. Duarte, D. Krause-Jensen, and N. Marbà. 2011. Connecting the dots: responses of coastal ecosystems to changing nutrient concentrations. Environmental Science \& Technology 45: 9122-9132.

Cloern, J.E. 1982. Does the benthos control phytoplankton biomass in south San Francisco Bay? Marine Ecology Progress Series 9: 191202.

Cloern, J.E., S.Q. Foster, and A.E. Kleckner. 2014. Phytoplankton primary production in the world's estuarine-coastal ecosystems. Biogeosciences 11: 2477-2501.

Conley, D., H. Kaas, F. Møhlenberg, B. Rasmussen, and J. Windolf. 2000. Characteristics of Danish estuaries. Estuaries 23: 820-837.

Conley, D.J., S. Markager, J.H. Andersen, T. Ellerman, and L.M. Svendsen. 2002. Coastal eutrophication and the Danish national 
aquatic monitoring and assessment program. Estuaries 25: 706719 .

Cullen, J.J. 1982. The deep chlorophyll maximum: comparing vertical profiles of chlorophyll a. Canadian Journal of Fisheries and Aquatic Sciences 39: 791-803.

Cushing, D.H. 1959. On the nature of production in the sea. Fish. Invest. Lond., Ser. 222: 1-40.

Cushing, D. H. 1972. The production cycle and the numbers of marine fish. Pages 213-232 Symp. Zool. Soc., London.

Domingues, R.B., T.P. Anselmo, A.B. Barbosa, U. Sommer, and H.M. Galvão. 2011. Light as a driver of phytoplankton growth and production in the freshwater tidal zone of a turbid estuary. Estuarine, Coastal and Shelf Science 91: 526-535.

Domingues, R.B., A. Barbosa, and H. Galvão. 2005. Nutrients, light and phytoplankton succession in a temperate estuary (the Guadiana, south-western Iberia). Estuarine, Coastal and Shelf Science 64: 249-260.

Edler, L. 1979. Phytoplankton and chlorophyll in Reccomendations on methods for marine biological studies in the Baltic Sea. Baltic Working Group 9 and The National Swedish Environment Protection Board Malmö.

Eppley, R.W. 1972. Temperature and phytoplankton growth in the sea. Fishery Bulletin 70: 1063-1085.

Eriksen, N.T., and J.J.L. Iversen. 1995. Photosynthetic pigments as nitrogen stores in the cryptophyte alga Rhodomonas sp. Journal of Marine Biotechnology 3: 193-195.

Falkowski, P.G., Z. Dubinsky, and K. Wyman. 1985. Growth-irradiance relationships in phytoplankton. Limnology and Oceanography 30: 311-321.

Fennel, K., and E. Boss. 2003. Subsurface maxima of phytoplankton and chlorophyll: steady-state solutions from a simple model. Limnology and Oceanography 48: 1521-1534.

Gallegos, C.L. 2014. Long-term variations in primary production in a eutrophic subestuary. I. Seasonal and spatial patterns. Marine Ecology Progress Series 502: 53-67.

Geider, R.J. 1987. Light and temperature dependence of the carbon to chlorophyll a ratio in microalgae and cyanobacteria: implications for physiology and growth of phytoplankton. New Phytologist 106: 134.

Grasshoff, K., K. Kremling, and M. Ehrhardt. 1999. Methods of seawater analysis. 3 edition. Wiley-VCH.

Gustafsson, B.G. 2000. Time-dependent modeling of the Baltic entrance area. 2. Water and salt exchange of the Baltic Sea. Estuaries 23: 253-266.

Hansen, B.W., P.K. Bjørnsen, and P.J. Hansen. 1994. The size ratio between planktonic predators and their prey. Limnology and Oceanography 39: 395-403.

Hansen, B.W., E. Stenalt, J.K. Petersen, and C. Ellegaard. 2002. Invertebrate re-colonisation in Mariager Fjord (Denmark) after severe hypoxia. I. Zooplankton and settlement. Ophelia 56: 197-213.

Hansen, P.J., P.K. Bjornsen, and B.W. Hansen. 1997. Zooplankton grazing and growth: scaling within the $\$ 2-2,000$-Imum $\$$ body size range. Limnology and Oceanography 42: 687-704.

Hay, S.J., T. Kiørboe, and A. Matthews. 1991. Zooplankton biomass and production in the North Sea during the Autumn Circulation experiment, October 1987-March 1988. Continental Shelf Research 11: 1453-1476.

Henriksen, P., B. Riemann, H. Kaas, H.M. Sørensen, and H.L. Sørensen. 2002. Effects of nutrient-limitation and irradiance on marine phytoplankton pigments. Journal of Plankton Research 24: 835-858.

Henson, S.A., J.L. Sarmiento, J.P. Dunne, I. Lima, S.C. Doney, J. John, and C. Beaulieu. 2010. Detection of anthropogenic climate change in satellite records of ocean chlorophyll and productivity. Biogeosciences 7: 621-640.
Hillebrand, H., C. Dürselen, D. Kirschtel, U. Pollingher, and T. Zohary. 1999. Biovolume calculation for pelagic and benthic microalgae. Journal of Phycology 35: 403-424.

Holligan, P.M., and D.S. Harbour. 1977. The vertical distribution and succession of phytoplankton in the western English Channel in 1975 and 1976. Journal of the Marine Biological Association of the United Kingdom 57: 1075-1093.

Jakobsen, H.H., J. Carstensen, P.J. Harrison, and A. Zingone. 2015. Estimating time series phytoplankton carbon biomass: inter-lab comparison of species identification and comparison of volume-tocarbon scaling ratios. Estuarine, Coastal and Shelf Science 162: $143-150$.

Jakobsen, H. H., and S. Markager. 2016. Carbon to chlorophyll ratio for phytoplankton in temperate coastal waters: seasonal patterns and relationship to nutrients. Limnology and Oceanography Accepted.

Kemp, M.W., and W.R. Boynton. 1984. Spatial and temporal coupling of nutrient inputs to estuarine primary production: the role of particulate transport and decomposition. Bulletin of Marine Science 35: $522-535$

Kiørboe, T. 1993. Turbulence, phytoplankton cell size, and the structure of pelagic food webs. Advances in marine biology 29: 1-72.

Kiørboe, T., and T.G. Nielsen. 1994. Regulation of zooplankton biomass and production in a temperate, coastal ecosystem. 1. Copepods. Limnology and Oceanography 39: 493-507.

Koski, M., and T. Kiørboe. 2005. Benthic life in the pelagic: aggregate encounter and degradation rates by pelagic harpacticoid copepods. Limnology and Oceanography 50: 1254-1263.

Kaas, H., and S. Markager. 1998. Technical guidelines for marine monitoring National Environmental Research Institute, Denmark.

Lewis, M.R., J.J. Cullen, and T. Platt. 1984. Relationships between vertical mixing and photoadaptation of phytoplankton: similarity criteria. Marine Ecology Progress Series 15: 141-149.

Lund-Hansen, L.C., M.H. Nielsen, A. Bruhn, C. Christiansen, T. Vang, P. Casado-Amezua, K. Richardson, and L. Santaloria. 2008. A consistent high primary production and chlorophyll-a maximum in a narrow strait - effects of hydraulic control. Journal of Marine Systems 74: 395-405.

Lyngsgaard, M.M., S. Markager, and K. Richardson. 2014a. Changes in the vertical distribution of primary production in response to landbased N-loading. Limnology and Oceanography 59: 1679-1690.

Lyngsgaard, M.M., K. Richardson, S. Markager, H.N. Nielsen, M. Olesen, and J.P.A. Christensen. 2014b. Deep primary production in coastal pelagic systems: importance for ecosystem functioning. Marine Ecology Progress Series 517: 15-33.

Markager, S. 1998. Dark uptake of inorganic14C in oligotrophic oceanic waters. Journal of Plankton Research 20: 1813-1836.

Markager, S., T. G. Nielsen, J. Carstensen, D. Conley, K. Dahl, J. Hansen, P. Henriksen, A. Josefson, M. M. Larsen, B. Pedersen, B. Rasmussen, J. Strand, G. Ærtebjerg, H. Fossing, J. S. Lauersen, O. Hertel, H. Skov, L. M. Svendsen, M. Cleemann, and G. Pritzl. 1999a. Marine områder. Status over miljøtilstanden i 1998. NOVA 2003. National Environmental Research Institute.

Markager, S., W. Vincent, and E.Y. Tang. 1999b. Carbon fixation by phytoplankton in high Arctic lakes: implications of low temperature for photosynthesis. Limnology and Oceanography 44: 597-607.

Mohlenberg, F. 1987. A submersible net pump for quantitative zooplankton sampling: comparison with conventional net sampling. Ophelia 27: $101-110$.

Morán X.A.G., and M. Estrada. 2005. Winter pelagic photosynthesis in the NW Mediterranean. Deep-Sea Research Part I 52: 1806-1822. doi:10.1016/j.dsr.2005.05.009.

Morán, X.A.G., and R. Scharek. 2015. Photosynthetic parameters and primary production, with focus on large phytoplankton, in a temperate mid-shelf ecosystem. Estuarine, Coastal and Shelf Science 154: 255-263. 
Maar, M., S. Markager, K.S. Madsen, J. Windolf, M.M. Lyngsgaard, H.E. Andersen, and E.F. Møller. 2016. The importance of local versus external nutrient loads for $\mathrm{Chl}$ a and primary production in the Western Baltic Sea. Ecological Modelling 320: 258-272.

Nielsen, E.S. 1952. The use of radio-active carbon (14C) for measuring organic production in the sea. Journal du Conseil International pour l'Exploration de la Mer 18: 117-140.

Nielsen, T.G., B. Løkkegaard, K. Richardson, F.B. Pedersen, and L. Hansen. 1993. Structure of plankton communities in the Dogger Bank area (North Sea) during a stratified situation. Marine Ecology Progress Series 95: 115-131.

Perry, M.J., B.S. Sackmann, C.C. Eriksen, and C.M. Lee. 2008. Seaglider observations of bloom and subsurface chlorophyll maxima off the Washington coast. Limnology and Oceanography 53: 2169-2179.

Peterson, B.J. 1980. Aquatic primary productivity and the ${ }^{14} \mathrm{C}-\mathrm{CO}_{2}$ method: a history of the productivity problem. Annual review of ecology and sytematics 11: 369-385.

Platt, T., and S. Sathyendranath. 2008. Ecological indicators for the pelagic zone of the ocean from remote sensing. Remote Sensing of Environment 112: 3426-3436.

Pomeroy, L.R., C.F. D'Elia, and L.C. Schaffner. 2006. Limits to topdown control of phytoplankton by oysters in Chesapeake Bay. Marine Ecology Progress Series 325: 301-309.

Richardson, K. 1991. Comparison of ${ }^{14} \mathrm{C}$ primary production determinations made by different laboratories. Marine Ecology Progress Series 72: 189-201.

Sabatini, M., and T. Kiørboe. 1994. Egg production, growth and development of the cyclopoid copepod Oithona similis. Journal of Plankton Research 16: 1329-1351.

Satapoomin, S. 1999. Carbon content of some common tropical Andaman Sea copepods. Journal of Plankton Research 21: 2117 2123.

Savchuk, O.P. 2005. Resolving the Baltic Sea into seven subbasins: N and P budgets for 1991-1999. Journal of Marine Systems 56: 1-15.
Standards, D. 1986. Water examination 2201. Klorofyl a. Spektrofotometrisk måling i ethanolekstrakt inklusive referencer heri. Danish Standards. Water examination 2201. [Chlorophyll $a$. Spectrophotometric measurement in ethanol extracts]. References included.

Strickland, J.D.H., and T.R. Parsons. 1972. A practical handbook of seawater analysis. Bulletin of the Fisheries Research Board of Canada 167: $1-310$.

Tang, E.P.Y. 1996. Why do dinoflagellates have lower growth rates? Journal of Phycology 32: 80-84.

Thompson, P. 2005. Effects of temperature and irradiance on marine microalgal growth and physiology. In Algal cultures, analogues of blooms and applications. USA: Science Publishers Inc.

Timmermann, K., S. Markager, and K.E. Gustafsson. 2010. Streams or open sea? Tracing sources and effects of nutrient loadings in a shallow estuary with a 3D hydrodynamic-ecological model. Journal of Marine Systems 82: 111-121.

Tiselius, P., A. Belgrano, L. Andersson, and O. Lindahl. 2015. Primary productivity in a coastal ecosystem: a trophic perspective on a longterm time series. Journal of Plankton Research 0: 1-11.

Utermöhl, H. 1958. Zur vervollkommung der quantitativen phytoplankton methodik. Mitteilungen Internationale Vereinigung fur Theoretische und Angewandte Limnologie 9: 1-38.

Verity, P.G. 1981. Effects of temperature, irradiance, and daylength on the marine diatom Leptocylindrus danicus Cleve. 1. Photosynthesis and cellular composition. Journal of Experimental Marine Biology and Ecology 55: 79-91.

Yoder, J.A. 1979. Effect of temperature on light limited growth and chemical composition of Skeletonema costatum (Bacillariophyceae). Journal of Phycology 15: 362-370.

Zervoudaki, S., T.G. Nielsen, and J. Carstensen. 2009. Seasonal succession and composition of the zooplankton community along an eutrophication and salinity gradient exemplified by Danish waters. Journal of Plankton Research 31: 1475-1492. 